\title{
EVALUASI KEBERLANJUTAN SISTEM PENGELOLAAN SUMBERDAYA AIR "HIPPAM" PADA MASYARAKAT DESA PANDANREJO KECAMATAN BUMIAJI, BATU JAWA TIMUR
}

\author{
Dwi Fauzia Putra ${ }^{1}$, Nila Restu Wardani ${ }^{2}$
}

E-mail: dwifauziaputra@gmail.com,ou.neyl@gmail.com

\begin{abstract}
Abstrak: Krisis air di Indonesia merupakan fenomena yang hampir selalu terjadi setiap musim kemarau. Pengelolaan yang berkelanjutan dibutuhkan untuk menghindari kekurangan air. Model pengelolaan apapun oleh masyarakat harus memasukkan dimensi lingkungan, sosial, dan ekonomi secara terpadu dan menyeluruh. Salah satu bentuk pengelolaan sumber daya air berbasis masyarakat adalah HIPPAM (Himpunan Penduduk Pemakai Air Minum) di Dusun Krajan Desa Pandanrejo Kec. Bumiaji, Batu-Jawa Timur. Tujuan penulisan artikel untuk mengetahui status keberlanjutan sistem pengelolaan sumber daya air HIPPAM. Metode survai digunakan mengevaluasi status keberlanjutan sistem pengelolaan sumber daya air HIPPAM. Analisis data keberlanjutan dengan mengukur atribut lingkungan, sosial, dan ekonomi. Pengkategorian status keberlanjutan dengan menghitung rata-rata perolehan skor keberlanjutan secara keseluruhan dan secara dimensional. Hasil analisis data menunjukkan bahwa sistem pengelolaan sumber daya air HIPPAM termasuk pada kategori cukup berkelanjutan. Masing masing dimensi juga termasuk dalam kategori cukup berkelanjutan. Hal ini menandakan bahwa pengelolaan sumberdaya air tidak hanya berorientasi pada salah satu dimensi saja namun telah terjadi sinergi atau keterpaduan antara dimensi lingkungan, sosial, dan ekonomi dalam pengelolaan sumberdaya air.
\end{abstract}

Kata Kunci: Pengelolaan Berkelanjutan, Sumberdaya Air, HIPPAM

\section{PENDAHULUAN}

Krisis air di Indonesia merupakan fenomena yang hampir selalu terjadi setiap musim kemarau padahal jika dilihat dari kondisi geografisnya Indonesia merupakan negara kepulauan memanjang di sekitar khatulistiwa dengan luas wilayah daratan sekitar $19,90 \%$ dan selebihnya $80,10 \%$ adalah perairan (Bonawati, 2012). Melihat kenyataan tersebut berarti faktor alam dan manusia turut berperan dalam terjadinya krisis air. Kodoatie (2008) menyatakan bahwa kerusakan lingkungan yang secara implisit menam- bah lajunya krisis air dipercepat oleh pertumbuhan penduduk yang tinggi, baik secara alami ataupun migrasi.

KTT Bumi (Earth Summit) yang diselenggarakan Bulan Juni 1992 di Rio de Janeiro mencetuskan Deklarasi Rio yang menyatakan bahwa pembangunan nasional semua negara dalam bentuk semua model apapun harus memasukkan dimensi lingkungan secara terpadu dan menyeluruh (Technical Advisory Committee, Global Water Partnership, 2001). Deklarasi ini dikenal dengan Agenda-21 
global yang oleh Indonesia diikuti dengan Agenda-21 Indonesia. Ide pokok agenda ini adalah model pembangunan berkelanjutan yang memadukan antara dimensi-dimensi ekonomi, sosial, dan lingkungan.

Berdasarkan uraian di atas maka dalam pengelolaan sumber daya air hendaknya memadukan dimensi ekonomi, sosial, dan lingkungan. Keterpaduan antara dimensi ekonomi, sosial, dan lingkungan adalah wujud dari konsep pengelolaan sumber daya air berkelanjutan. Model pengelolaan sumber daya air harus membentuk keterpaduan antara manusia dan alam. Hal ini berarti lingkungan fisik dan lingkungan budaya manusia saling berkaitan. Kerusakan terhadap salah satu dimensi akan diikuti oleh kerusakan dimensi lainnya.

Perspektif kelingkungan dalam studi geografi menelaah fenomena sebagai wujud dari keterkaitan atau hubungan timbal balik antara organisme hidup dengan lingkungannya. Dalam lingkup analisis keterkaitan antara oganisme hidup dengan lingkungannya, sosok biologis yang bisa merupakan faktor pengaruh namun juga dapat berperan sebagai faktor yang dipengaruhi (Yunus, 2010). Temuan Hamdani (2014) bahwa dalam mengelola lingkungan yang dilakukan masyarakat melalui system agropolitan di Poncokusumo terdapat berbagai dimensi keberlanjutan yang belum terpenuhi selain yang sudah memenuhi untuk mendukung pembangunan berkelanjutan. Rahayu (2013) menemukan hasil analisis indeks keberlanjutan menunjukkan Kota Batu sebagai kawasan agropolitan ditinjau dari dimensi ekologi kurang berkelanjutan, dimensi ekonomi cukup berkelanjutan, dimensi sosial kurang berkelanjutan dan dimensi infrastruktur kurang berkelanjutan. Berdasarkan hasil analisis perlu dilakukan perbaikan dari dimensi ekologi lebih utama dengan menerapkan sistem pertanian organik sebagai dasar dalam peningkatan pengembangan kawasan agropolitan.

Salah satu bentuk pengelolaan sumber daya air adalah yang berbasis masyarakat adalah HIPPAM di Dusun Kajar Desa Pandanrejo Kec. Bumiaji, Batu Jawa Timur. HIPPAM (Himpunan Penduduk Pemakai Air Minum) merupakan organisasi pengelolaan air minum lokal yang dibangun masyarakat. Sistem ini dibentuk dari ketidaksamaan persepsi masyarakat lokal dengan pemerintah tentang pegelolaan sumber daya air. PDAM Kota Batu menjadikan sumber daya air sebagai bisnis dan masyarakat sebagai konsumen. Biaya yang mahal dan pelayanan yang tidak memuaskan oleh PDAM ini yang selanjutnya membuat masyarakat keluar sebagai pelanggan dan mendirikan HIPPAM (Susilo, 2013).

Sistem ini terbukti mampu menjadi solusi bagi masyarakat Pandanrejo. Selain itu air juga dapat dibagikan secara merata kepada seluruh masyarakat setempat dengan biaya yang relatif murah. Ini mengindikasikan bahwa sistem HIPPAM memiliki keunggulan tersendiri bagi masyrakat. Namun di sisi lain pengelolaan dengan sistem HIPPAM juga perlu mempertimbangkan aspek keberlanjutan di masa yang akan datang. Apakah sistem yang dijalankan saat ini sudah mengintegrasikan dimensi ekonomi dengan dimensi sosial dan lingkungan. Berdasarkan uraian tersebut maka perlu untuk mengungkapkan bagaimanakah status 
Dwi Fauzia Putra, Nila Restu Wardani. Evaluasi Keberlanjutan Sistem Pengelolaan Sumberdaya Air "HIPPAM" Pada Masyarakat Desa Pandanrejo Kecamatan Bumiaji, Batu Jawa Timur

keberlanjutan sistem pengelolaan sumber daya air HIPPAM pada masyarakat Dusun Kajar Desa Pandanrejo Kec. Bumiaji Batu-Jawa Timur.

\section{METODE}

Pengumpulan data menggunakan metode survai evaluatif untuk mengevaluasi pelaksanaan suatu program. Survai adalah penelitian yang mengambil sampel dari satu populasi dan menggunakan kuesioner sebagai alat pengumpulan data yang pokok (Singarimbun, 1995). Analisis keberlanjutan HIPPAM dilakukan melalui perhitungan rata-rata skor perolehan tiap atribut pada masingmasing dimensi keberlanjutan. Selanjutnya untuk mengetahui keberlanjutan secara keseluruhan diperoleh dari ratarata skor perolehan dari ketiga dimansi keberlanjutan yang mencakup dimensi lingkungan, sosial, dan ekonomi. Pengambilan keputusan dilakukan dengan membandingkan skor perolehan dengan kategori keberlanjutan menurut Thamrin (dalam Hamdani, 2014) sehingga diperoleh kategori-kategori keberlanjutan HIPPAM baik secara keseluruhan atau secara dimensional.

Tabel 1. Kategori Status Keberlanjutan

\begin{tabular}{ll}
\hline Nilai Indeks & Kategori \\
\hline $0,00-24,99$ & Buruk (Tidak Berkelanjutan) \\
$25,00-49,99$ & Kurang (Kurang Berkelanjutan) \\
$50,00-74,99$ & Cukup (Cukup Berkelanjutan) \\
$75,00-100,00$ Baik & (Sangat Berkelanjutan) \\
\hline
\end{tabular}

Sumber: Thamrin dalam Hamdani, 2014.

\section{HASIL PENELITIAN}

\section{Keberlanjutan Dimensi Lingkungan}

Analisis terhadap dimensi lingkungan dilakukan dengan menganalisis skor terhadap masing-masing atribut lingkungan. Atribut yang digunakan meliputi: konservasi sumberdaya air, pengelolaan kualitas air, pengendalian pencemaran air, tingkat kerusakan lahan, dan perubahan penggunaan lahan vegetasi menjadi non vegetasi maupun menjadi lahan terbangun. Hasil analisis menun- jukkan bahwa dimensi lingkungan termasuk pada kategori cukup berkelanjutan dengan nilai 59,4. Jika dilihat dari masing-masing atribut terdapat satu atribut yang menunjukkan tidak berkelanjutan, dua atribut pada kategori cukup berkelanjutan, dan dua atribut pada kategori sangat berkelanjutan. Untuk lebih detailnya dapat dilihat pada tabel berikut ini. 
Tabel 2. Keberlanjutan Dimensi Lingkungan

\begin{tabular}{llll}
\hline DIMENSI LINGKUNGAN & & \\
\hline NO & ATRIBUT & SKOR KEBERLANJUTAN & KETERANGAN \\
\hline 1 & Konservasi sumberdaya air & 50 & Cukup berkelanjutan \\
2 & Pengelolaan kualitas air & 75,7 & Sangat berkelanjutan \\
3 & Pengendalian pencemaran air & 97,1 & Sangat berkelanjutan \\
4 & Tingkat kerusakan lahan & 71,4 & Cukup berkelanjutan \\
5 & Perubahan penggunaan lahan veg- & 2,8 & Tidak berkelanjutan \\
& etasi menjadi non vegetasi maupun & & \\
& menjadi lahan terbangun & & Cukup berkelanjutan \\
RATA-RATA & 59,4 &
\end{tabular}

\section{Keberlanjutan Dimensi Sosial}

Analisis terhadap dimensi sosial dilakukan dengan menganalisis skor terhadap masing-masing atribut sosial. Atribut yang digunakan meliputi: Tingkat pendidikan formal, pelatihan pengelolaan sumberdaya air, pemerataan pendayagunaan sumberdaya air, kerjasaama dengan para pihak dalam pendayagunaan sumber daya air, partisipasi masyarakat dalam pengelolaan sumberdaya air, kepedulian masyarakat, dukungan budaya lokal, sikap tolong menolong antar masyarakat pengguna sumberdaya air, akses masyarakat terhadap sumberdaya air, konflik sosial antar masyarakat pengguna sumberdaya air

Hasil analisis menunjukkan bahwa dimensi sosial termasuk pada kategori cukup berkelanjutan dengan nilai 73,68. Jika dilihat dari masing-masing atribut terdapat satu atribut yang menunjukkan kategori tidak berkelanjutan, satu atribut pada kategori kurang berkelanjutan, satu atribut pada kategori cukup berkelanjutan, dan tujuh atribut pada kategori sangat berkelanjutan. Untuk lebih detailnya dapat dilihat pada tabel berikut ini. 
Dwi Fauzia Putra, Nila Restu Wardani. Evaluasi Keberlanjutan Sistem Pengelolaan Sumberdaya Air "HIPPAM" Pada Masyarakat Desa Pandanrejo Kecamatan Bumiaji, Batu Jawa Timur

\section{Tabel 3. Keberlanjutan Dimensi Sosial}

\begin{tabular}{|c|c|c|c|}
\hline \multicolumn{4}{|c|}{ DIMENSI SOSIAL } \\
\hline NO & ATRIBUT & SKOR KEBERLANJUTAN & KETERANGAN \\
\hline 1 & Tingkat pendidikan formal & 20 & Tidak berkelanjutan \\
\hline 2 & $\begin{array}{l}\text { Pelatihan pengelolaan sumberdaya } \\
\text { air }\end{array}$ & 50 & Cukup berkelanjutan \\
\hline 3 & $\begin{array}{l}\text { Pemerataan pendaya gunaan sumber } \\
\text { daya air }\end{array}$ & 94,2 & Sangat berkelanjutan \\
\hline 4 & $\begin{array}{l}\text { Kerjasaama dengan para pihak da- } \\
\text { lam pendaya gunaan sumber daya } \\
\text { air }\end{array}$ & 35,7 & Kurang berkelanjutan \\
\hline 5 & $\begin{array}{l}\text { Partisipasi masyarakat dalam } \\
\text { pengelolaan sumberdaya air }\end{array}$ & 92,8 & Sangat berkelanjutan \\
\hline 6 & Kepedulian masyarakat & 87,1 & Sangat berkelanjutan \\
\hline 7 & Dukungan budaya lokal & 85,7 & Sangat berkelanjutan \\
\hline 8 & $\begin{array}{l}\text { Sikap tolong menolong antar } \\
\text { masyarakat pengguna sumberdaya } \\
\text { air }\end{array}$ & 87,1 & Sangat berkelanjutan \\
\hline 9 & $\begin{array}{l}\text { Akses masyarakat terhadap sum- } \\
\text { berdaya air }\end{array}$ & 97,1 & Sangat berkelanjutan \\
\hline 10 & $\begin{array}{l}\text { Konflik sosial antar masyarakat } \\
\text { pengguna sumberdaya air }\end{array}$ & 87,1 & Sangat berkelanjutan \\
\hline RAT & -RATA & 73,68 & Cukup berkelanjutan \\
\hline
\end{tabular}

\section{Keberlanjutan Dimensi Ekonomi}

Analisis terhadap dimensi lingkungan dilakukan dengan menganalisis skor masing-masing atribut ekonomi. Atribut yang digunakan meliputi: tingkat pendapatan, tarif penggunaan sumberdaya air, pelayanan terhadap penggunaan sumber daya air, denda polusi, pengusahaan air dan ijin perdagangan, subsidi penggunaan sumberdaya air. Hasil analisis menunjukkan bahwa di- mensi ekonomi termasuk pada kategori cukup berkelanjutan dengan nilai 72,1 . Jika dilihat dari masing-masing atribut terdapat satu atribut yang menunjukkan pada kategori tidak berkelanjutan, satu atribut pada kategori kurang berkelanjutan, dan empat atribut pada kategori sangat berkelanjutan. Untuk lebih detailnya dapat dilihat pada tabel berikut ini. 
Tabel 3. Keberlanjutan Dimensi Ekonomi

\begin{tabular}{llll}
\hline DIMENSI EKONOMI & & \\
\hline NO & ATRIBUT & SKOR KEBERLANJUTAN & KETERANGAN \\
\hline 1 & Tingkat pendapatan & 44,2 & Kurang berkelanjutan \\
2 & Tarif penggunaan sumberdaya air & 98,5 & Sangat berkelanjutan \\
3 & Pelayanan terhadap pengugunaan sumber & 97,4 & Sangat berkelanjutan \\
& daya air & & \\
4 & Denda polusi & 17,1 & Tidak berkelanjutan \\
5 & Pengusahaan air dan ijin perdagangan & 100 & Sangat berkelanjutan \\
6 & Subsidi pendayagunaan sumberdaya air & 75,7 & Sangat berkelanjutan \\
RATA-RATA & 72,15 & Cukup berkelanjutan \\
\hline
\end{tabular}

\section{Status Keberlanjutan Pengelolaan Sumberdaya Air Secara Keseluruhan}

Analisis terhadap status keberlanjutan pengelolaan sumberdaya air HIPPAM di-lakukan dengan melihat rata-rata nilai yang diperoleh untuk masing-masing dimensi keberlanjutan. Dimensi yang digunakan meliputi lingkungan, sosial, dan ekonomi. Hasil analisis menunjukkan bahwa HIPPAM dalam mengelola sumberdaya air termasuk pada kategori cukup berkelanjutan dengan nilai 68,39. Jika dilihat dari masing-masing dimensi, keseluruhan dimensi tergolong pada kategori cukup berkelanjutan. Untuk lebih detailnya dapat dilihat pada tabel berikut ini.

Tabel 4. Status Keberlanjutan Hippam

\begin{tabular}{llll}
\hline \multicolumn{2}{l}{ STATUS KEBERLANJUTAN HIPPAM } & \\
\hline NO & DIMENSI & SKOR & KETERANGAN \\
\hline 1 & Lingkungan & 59,4 & Cukup berkelanjutan \\
2 & Sosial & 73,64 & Cukup berkelanjutan \\
3 & Ekonomi & 72,15 & Cukup berkelanjutan \\
RATA-RATA & 68,39 & Cukup berkelanjutan \\
\hline
\end{tabular}

\section{PEMBAHASAN}

Berdasarkan temuan penelitian bahwa status keberlanjutan pengelolaan sumberdaya air oleh masyarakat atau dikenal dengan HIPPAM termasuk dalam kategori cukup berkelanjutan. Hal ini menandakan bahwa pengelolaan sumberdaya khususnya air yang dilakukan oleh masyarakat mendukung akan keberlanjutan sumberdaya tersebut. Susilo (2012) menjelaskan bahwa pengelolaan air berbasis masyarakat merupakan tero- bosan pengelolaan air dimana sumber air dapat dikelola bersama secara terbuka, efisien, partisipatif, demokratis dan berkeadilan sosial.

Pengelolaan sumberdaya air oleh masyarakat melalaui Hippam ditemukan telah terjadi sinergi antara aspek lingkungan, sosial, dan ekonomi. Hasil analisis sata menunjukkan masing-masing dimensi keberlanjutan termasuk kategori yang cukup berkelanjutan. Mitchel (2010) 
Dwi Fauzia Putra, Nila Restu Wardani. Evaluasi Keberlanjutan Sistem Pengelolaan Sumberdaya Air "HIPPAM" Pada Masyarakat Desa Pandanrejo Kecamatan Bumiaji, Batu Jawa Timur

menyatakan bahwa etika berkelanjutan dalam pengelolaan sumber daya air meliputi keterpaduan ekologi dan keanekaragaman hayati untuk lingkungan sehat, ekonomi yang dinamis, pemerataan sosial untuk generasi sekarang dan yang akan datang. Sinergi antara ketiga dimensi keberlanjutan ini menandakan pengelolaan sumberdaya telah memenuhi syarat utama bagi keberlanjutan suatu sumberdaya di masa datang. Keberlanjutan berarti sumberdaya air mempunyai fungsi sosial yang berarti kepentingan umum lebih diutamakan daripada kepentingan individu, lingkungan hidup yang berarti bahwa sumberdaya air menjadi bagian dari ekosistem tempat kelangsungan hidup flora dan fauna, dan ekonomi yang berarti bahwa sumberdaya air dapat memberikan manfaat secara ekonomi bagi masyarakat.

Keberlanjutan pengelolaan sumberdaya air oleh masyarakat melalui HIPPAM ini tidak lepas dari peran atribut-atribut keberlanjutan pada masingmasing dimensi. Atribut yang berhubungan dengan dimensi lingkungan melalui upaya pelestarian menunjukkan kategori cukup berkelanjutan dan sangat berkelanjutan. Hal ini menandakan bahwa masyarakat telah mampu melindungi sumberdaya air dari kerusakan baik yang disebabkan oleh alam maupun manusia. Namun pada atribut perubahan penggunaan lahan menunjukkan kategori tidak berkelanjutan. Kondisi ini tidak lepas dari pertumbuhan penduduk diikuti dengan pertumbuhan permukiman. Selain itu juga faktor perkembangan yang semakin pesat dari aktivitas ekonomi agrowisata yang mulai berkembang di kota Batu.

Keberlanjutan dimensi sosial juga tidak lepas dari atribut-atribut di dalamnya. Terdapat tujuh atribut pada kategori sangat berkelanjutan. Pemerataan pendayagunaan sumber daya air, artisipasi masyarakat dalam pengelolaan sumberdaya air, kepedulian masyarakat, sikap tolong menolong antar masyarakat pengguna sumberdaya air, akses masyarakat terhadap sumberdaya air, dan tidak adanya konflik sosial antar masyarakat pengguna sumberdaya air merupakan atribut-atribut dengan kategori sangat berkelanjutan dan berperan penting dalam keberlanjutan sumberdaya air. Hal tersebut mengindikasikan bahwa masyarakat memiliki modal sosial yang kuat.

Modal sosial ini sebagai pengendali perilaku masyarakat dalam memanfaatkan sumberdaya alam dengan bijaksana. Modal sosial menggerakkan masyarakat untuk sadar secara bersama-sama mengelola dan menjaga sumberdaya air serta mengatasi permasalahan secara bersama serta mendahulukan kepentingan masyarakat daripada kepentingan individu. Tersedianya stok modal sosial yang besar akan memfasilitasi terjadinya transaksi antar individu, rumah tangga, dan kelompok yang efisien melalui tersedianya informasi dengan biaya rendah, terdapat kemudahan semua pihak mencapai keputusan kolektif, berkurangnya perilaku oportunistik dari anggota masyarakat (Vipriyanti, 2011).

Terdapat atribut lain yang juga memiliki peran penting dalam keberlanjutan pengelolaan sumberdaya 
air ini yaitu peran budaya lokal. Budaya lokal disini adalah yang berkaitan tradisi masyarakat yang berhubungan dengan sumber air. Selamatan desa dan selamatan sumber merupakan tradisi yang dilakukan oleh masyarakat yang secara tidak langsung ikut melestarikan sumber air. Berdasarkan wawancara dengan salah satu pamong desa bahwa selamatan sumber berhubungan dengan keyakinan bahwa sumber mata air ada yang menjaga sehingga perlu diselamati. Selain itu juga ungkapan syukur atas keberlimpahan sumberdaya air yang sangat berguna bagi kelangsungan hidup masyarakat. Hal ini sejalan dengan temuan-temuan sebelumnya bahwa pelestarian lingkungan berbasis masyarakat melalui budaya lokal berupa kearifan lokal telah terbukti berhasil mengendalikan perilaku masyarakat dan melindungi lingkungan dari kerusakan di berbagai konteks lokasi dan sosial (Fatchan dkk, 2016; Sumarmi, 2015; Zuhud, 2009; Boedihartono, 2009).

Atribut yang juga berperan penting terhadap keberlanjutan pengelolaan sumberdaya adalah tidak terdapat konflik sosial dalam masyarakat. Temuan penelitian menunjukkan bahwa pada masyarakat hampir tidak pernah ditemui konflik sosial dikarenakan perebutan sumberdaya air. Atribut ini tergolong dalam kategori sangat berkelanjutan. Pasandaran (2002) menyatakan bahwa ancaman terhadap pengelolaan sumber daya air selama ini adalah kegagalan masyarakat dalam memenuhi kebutuhan air, terjadinya krisis air dan konflik perebutan sumber air. Hal ini berarti bahwa kebersamaan masyarakat dan saling percaya antar anggota masyarakat telah berhasil meredam adan- ya konflik sosial yang mengancam keberlanjutan sumberdaya air.

Pada dimensi sosial terdapat satu atribut yang tergolong pada kategori tidak berkelanjutan yaitu atribut pendidikan formal. hasil analisis menunjukkan bahwa rata-rata penduduk adalah lulusan SMP dan SD. Rendahnya tingkat pendidikan formal secara tidak langsung juga akan dapat mengancam keberlanjutan. Pendidikan berkaitan dengan pengetahuan masyarakat akan lingkungannya. Pengetahuan meskipun tidak berpengaruh secara langsung namun dapat mempengaruhi persepsi, nilai dan sikap seseorang dalam memendanh suatu sumberdaya. Persepsi, nilai, sikap yang baik akan menghasilkan perilaku yang melestarikan lingkungan, begitu juga sebaliknya.

Dimensi keberlanjutan berikutnya adalah dimensi ekonomi. Dimensi ekonomi tergolong pada kategori cukup berkelanjutan. Hal ini juga tidak lepas dari pengaruh setiap atribut pada dimensi ini yang sebagian besar tergolong pada kategori sangat berkelanjutan. HIPPAM memberikan akses yang mudah dengan tarif yang murah dibandingkan dengan tarif perusahaan yang dikelola negara. Hal ini turut berperan dalam pemerataan pendayagunaan sumberdaya air bagi semua golongan masyarakat. Hippam juga merupakan organisasi legal yang berdiri atas ijin yang resmi. Selain itu HIPPAM dalam mengelola sumberdaya air telah mampu berswadaya meskipun terkadang masih mendapat bantuan dari pemerintah berupa pipa. Kemampuan berswadaya menunjukkan bahwa masyarakat mampu mandiri dan tidak terlalu bergantung pada pemerintah atau pihak lain. 
Dwi Fauzia Putra, Nila Restu Wardani. Evaluasi Keberlanjutan Sistem Pengelolaan Sumberdaya Air "HIPPAM" Pada Masyarakat Desa Pandanrejo Kecamatan Bumiaji, Batu Jawa Timur

Hal yang perlu diantisipasi adalah atribut pendapatan dan denda polusi. Atribut pendapatan masyarakat menunjukkan kurang berkelanjutan. Sedangkan tidak adanya denda atas perilaku masyarakat yang menimbulkan polusi air berdampak pada keberlanjutan sumberdaya air di masa depan. Pendapatan yang rendah menandakan tingkat kemiskinan. Kemiskinan pada masyarakat merupakan salah satu pemicu seseorang untuk berperilaku merusak lingkungan. Meskipun saat ini kondisi tersebut masih dapat diimbangi dengan atribut-atribut lainnya namun perlu untuk segera diupayakan peningkatan terhadap pendapatan masyarakat sebab jika kondisi ekonomi masyarakat kurang berkelanjutan kelak akan berpengaruh terhadap kondisi sosial dan dapat mengancam keberlanjutan sumberdaya alam.

\section{KESIMPULAN}

Berdasarkan hasil penelitian dan pembahasan dapat ditarik kesimpulan bahwa status keberlanjutan pengelolaan sumberdaya air oleh masyarakat atau dikenal dengan HIPPAM pada masyarakat Dusun Krajan Desa Pandanrejo Kecamatan Bumiaji Kota Batu termasuk dalam kategori cukup berkelanjutan. Masing masing dimensi keberlanjutan juga termasuk dalam kategori cukup berkelanjutan. Nilai dimensi sosial adalah yang tertinggi diikuti dengan dimensi ekonomi dan dimensi lingkungan.

Secara keseluruhan pengelolaan sumberdaya air HIPPAM cukup berkelanjutan, sehingga saran yang diberikan bagi pengelola hendaknya meningkatkan sistem yang sudah ada melalui penguatan partisipasi-partisipasi masyarakatnya. Bagi pemerintah daerah hendaknya membantu masyarakat dalam upaya meningkatkan kualitas pendidikan dan pendapatan masyarakat yang masih randah karena kedua atribut tersebut penting untuk diperhatikan keberlanjutannya. Bagi peneliti selanjutnya hendaknya mengkaji kembali status keberlanjutan pengelolaan sumberdaya air berbasis masyarakat dengan menambahkan dimensi infrastruktur dan dimensi kelembagaan sehingga diperoleh informasi yang lebih rinci.

\section{DAFTAR PUSTAKA}

Boedihartono. 2009. Tanah Toa, Kajang, Bulukumba, Sulawesi Selatan. Dalam Herwasono Soedjito (Eds.), Situs Keramat Alami: Peran Budaya Dalam Konservasi Keanekaragaman Hayati (hlm.62-77) Jakarta: Yayasan Obor Indonesia.

Bonawati, Eva. 2012. Geografi Indonesia. Yogyakarta: Penerbit Ombak.

Fatchan, Ach. Soekamto, H. Amirudin, Ach. Nudia, A. 2016. Understanding Behaviour Environmental Education Water Resources Model of Outdoor Study on Community of "Osing" at Banyuwangi District East Java Indonesia. Research on Humanities and Social Sciences. Vol.6, No.6, 2016.

Hamdani, Akhmad Faruq. 2014. Perencanaan Pengembangan Wilayah Agropolitan Berkelanjutan dalam Mendukung Pembangunan Perdesaan (Studi Kasus Kecamatan Poncokusumo, Malang, Jawa Timur). Tesis. Bandung: Pascasarjana Universitas Padjadjaran. 
Kodoatie. Robert J. 2008. Pengelolaan Sumber Daya Air Terpadu. Yogyakarta: ANDI OFFSET.

Mitchell., Bruce, dkk. 2010. Pengelolaan Sumber Daya Alam dan Lingkungan. Yogyakarta: Gadjah Mada University Press.

Pasandaran, Effendi, dkk. 2002. Pengelolaan Lahan dan Air di Indonesia. Jakarta: Badan Penelitian dan Pengembangan Pertanian.

Rahayu, Ami.dkk. 2013. Strategi Peningkatan Status Keberlanjutan Kota Batu Sebagai Kawasan Agropolitaan. Jurnal EKOSAINS | Vol. V| No. 1 | Maret 2013.

Singarimbun, Masri \& Effendi, Sofian. 1995. Metode Penelitian Survei. Jakarta: PT. Pustaka LP3ES Indonesia.

Sumarmi. 2015. Wisdom of Osing People in Conserving Water Resource. Jurnal Komunitas, 7(1):43-51.

Susilo, Rachmad K Dwi. 2012. Model Demokratisasi Pengelolaan Sumber Daya Air Minum Melalui Pendekatan Transformatif dan Resolutif untuk Kesejahteraan Masyarakat. UMM: Direktorat Penelitian dan Pengabdian Kepada Masyarakat.
Susilo, Rachmad K Dwi. 2013. Pengembangan Model Co-Management Berbasis Pembelajaran Sosial (Social Learning) untuk Pencegahan Konflik Pengelolaan Sumber Daya Air Minum Bagi Masyarakat Sekitar Sumber Air Di Kota Batu. UMM: Direktorat Penelitian dan Pengabdian Kepada Masyarakat.

Technical Advisory Committee (TAC), Global Water Partnership (GWP). 2001. Integrated Water Resources Management. Toolbox. Stockholm. Sweden.

Vipriyanti, Nyoman. Utari. 2011. Modal Sosial dan Pembangunan Wilayah. Malang: Universitas Brawijaya Press.

Yunus, Hadi Sabari. 2010. Metode Penelitian Wilayah Kontemporer. Yogyakarta: Pustaka Pelajar.

Zuhud, Ervizal A.M. 2009. Trip-Stimulus AMAR sebagai Pendorong Sikap Konsevatif (Kasus Konservasi Kedawang di Taman Nasional Merubetiri. Dalam Herwasono Soedjito (Eds.), Situs Keramat Alami: Peran Budaya Dalam Konservasi Keanekaragaman Hayati (hlm.3-27) Jakarta: Yayasan Obor Indonesia. 